\title{
PROFESSIONAL NURSES' REQUESTS TO REMOVE THEIR NAMES FROM THE SOUTH AFRICAN NURSING COUNCIL'S REGISTER PART 1: INTRODUCTION AND LITERATURE REVIEW
}

\section{Dr Valerie J Ehlers}

B Soc Sc (Nursing); Honours BA (SS) (Psychology; BA Cur; Honours BA Cur; MA Cur; D Litt et Phil; Diploma in Development Studies

Senior Lecturer, Department of Health Studies, Unisa

Correspondence: ehlervj@unisa.ac.za

Keywords: baby boomers; migration of nurses; non-practising nurses; nurses' turnover; nursing shortages; professional re-entry of nurses; retirement of nurses

\section{SUMMARY}

Worldwide a severe shortage of professional nurses is expected to occur between 2005 and 2020 - when the "baby boomers" born between 1947 and 1962 reach retirement age. This shortage will differ from any previous shortage because there will be no large pool of non-practising professional nurses as was the case during the nurse shortages encountered during the 1980s. The countries paying better salaries will continue to attract professional nurses from the poorer paying countries (including the Republic of South Africa); further depleting their supplies of professional nurses. This scenario makes it imperative for poorer paying countries to start monitoring the professional nurses who leave the nursing profession, and make plans to address the potential crisis which could be precipitated by a severe shortage of professional nurses. This article discusses the shortage of nurses in South Africa and in other countries. The literature review addresses the anticipated shortage of professional nurses in a number of countries, concluding that a global shortage of nurses could be anticipated between 2005 and 2020 when the majority of nurses are expected to reach retirement ages. This discussion is followed by the problem statement, as well as the objectives for this research and the significance of investigating why South African nurses request their names to be removed from the SANC's register. The next article will describe the research process and results indicating why nurses in South Africa requested their names to be removed from the SANC's register.

\section{OPSOMMING}

Wêreldwyd word daar tussen 2005 en 2020 'n ernstige tekort aan professionele verpleegkundiges voorspel wanneer die "baby boomers" wat tussen 1947 en 1962 gebore is, gaan aftree. Hierdie tekort gaan verskil van enige vorige tekort omdat daar dan nie groot getalle nie-praktiserende professionele verpleegkundiges gaan wees soos tydens die 1980s se tekorte nie. Die lande wat beter salarisse betaal, sal voortgaan om professionele verpleegkundiges vanaf swakker betalende lande te werf (insluitende die Republiek van Suid-Afrika) - wat die swakker betalende lande se professionele verpleegkundiges verder gaan verminder. Hierdie scenario noodsaak die swakker betalende lande om daadwerklik die verpleegkundiges wat die verpleegberoep verlaat te monitor, ten einde die moontlike krisis wat kan ontstaan weens ' $n$ ernstige tekort aan verpleegkundiges, aan te spreek. Hierdie artikel bespreek verpleegtekorte in Suid-Afrika en in ander lande. Die literatuuroorsig spreek die verwagte tekort van verpleegkundiges in verskeie lande aan, wat lei tot die gevolgtrekking dat daar 'n wêreldwye tekort aan verpleegkundiges tussen 2005 en 2020 verwag kan word, wanneer die meeste verpleegkundiges aftreeouderdomme sal bereik. Die bespreking word gevolg deur die stelling van die navorsingsprobleem en doelwitte vir die studie asook ' $n$ aanduiding van die belangrikheid van navorsing oor redes waarom Suid-Afrikaanse verpleegkundiges versoek dat hulle name van die SARV se register verwyder word. Die volgende artikel bespreek die navorsingsproses en resultate aangaande redes waarom professionele verpleegkundiges in Suid-Afrika versoek dat hulle name van die SARV se register verwyder word. 


\section{INTRODUCTION AND BACKGROUND INFORMATION}

"Never before in the history of nursing has the shortage of professional nurses been so severe. From the southern tip of Florida to Canada, England, Ireland, Japan, South Africa, and Australia, the cry has gone out for nurses to fill long vacant positions. There are not enough nurses world wide to fill the demand, and the ripple of alarm has spread across the globe .... The shortage of registered nurses is projected to be 291000 in 2020 (in the United States of America). In the US $50 \%$ of the faculty in schools of nursing will retire by 2010" (Purnell, Horner, Gonzalez \& Westman, 2001:179). The American Association of Colleges of Nursing (AACN) predicts that a very conservative estimate of more than 100000 jobs for nurses in the USA will be unfilled by 2015 (Schader, Broome, Broome, West \& Nash, 2001:210). The National Institute of Nursing Research (NINR) in the USA indicates that although there are approximately 2.7 million registered nurses in the USA, this number only represents a $5.4 \%$ increase since 1996 , amounting to the lowest rate of increase since 1980 (News from NINR, 2003:1). This shortage of nurses in the USA is further aggravated by the fact that $20 \%$ (or 540000 of the 2.7 million registered nurses) were "not using their licenses" implying that they were not working as professional nurses in the USA (Colossi, 2002:50).

One way of addressing the nursing shortage is by enabling nurses from other countries to work in the USA. Large numbers of professional nurses registered with the South African Nursing Council (SANC) leave the Republic of South Africa (RSA) to work in better paying countries, with better working conditions (DENOSA, 2001:1). As long as there is a shortage of professional nurses worldwide, the emigration of professional nurses will continue draining developing countries' supplies of nurses, including the RSA. It cannot be assumed that developed countries will be able to supply the numbers of professional nurses required by their respective countries. For example, the government of the United Kingdom intends to recruit an additional 20000 professional nurses by 2004, and to retain the professional nurses they already have (Milburn, 2001:39). South African nurses, whose training as well as their ability to communicate in English are valued by many countries, could help to address the dire shortage of nurses in these countries, while enhancing their own standard of living (Christmas, 2002:20). For example, an American health care strategist proclaimed that "...South African ICU (intensive care unit) nurses have a scope of practice that surpasses that of the average US RN. For example, their duties also encompass some of the functions of respiratory therapists in the United States" (Christmas, 2002:2).

While the shortages of nurses in the USA and in the UK enable South African nurses to find employment in these (and other) countries, this emigration of nurses aggravates the shortage of nurses within South Africa. One way in which such a shortage could be addressed is by enabling non-practising nurses in the RSA to reenter the professionally active ranks of the nursing profession. Unfortunately no census exists of nonpractising professional nurses in the RSA. The only way of identifying non-practising nurses in the RSA is to obtain the names of those who requested their names to be removed from the SANC register during the annual compulsory renewal of such registration. The number of professional nurses who request their names to be removed from the SANC's registers on an annual basis, further reduces the number of RNs who can render nursing services in the RSA.

The direct results of a shortage of professional nurses include the closure of hospital wards and/or clinics, reducing the available health care services; leading to long waiting lists and/or periods at health care facilities. The major indirect result of such a shortage revolves around the increased workloads experienced by the remaining nurses, leading to perceptions of being overburdened, overstretched, and ineffective. Those professional nurses who can leave such situations, where little or no job satisfaction can be experienced, do leave, making the situation even worse for the professional nurses remaining in the situation. "In South Africa, hospitals are struggling with the exodus of nurses to richer countries ... left the country with a shortage of 20000 qualified staff. The South African Nursing Council says there are 175000 registered nurses in South Africa, a figure that has hardly grown in the past decade" (Ka Mzolo, 2001:38).

This article will describe the purpose, objectives and significance of studying reasons why professional 
nurses request that their names be removed from the SANC's register. Further justification for conducting this research will be based on a review of literature concerning specific issues which could impact on the anticipated global shortage of nurses, including: baby boomers, the training of more student nurses, the effects of a severe shortage of nurses on the nursing profession and the retention of professional nurses in the active professional ranks. Based on the literature reviewed, a serious global shortage of professional nurses can be expected between 2005 and 2020 emphasising the need to monitor all nurses who leave the profession, especially those who request that their names should be removed from the SANC registers, implying that they would not be legally allowed to practise their profession in the RSA.

\section{PROBLEM STATEMENT}

This research attempted to address the anticipated depletion of professional nurses in the RSA and to contribute to the avoidance of a potential crisis regarding the shortage of professional nurses in the RSA.

\section{OBJECTIVES OF THE RESEARCH}

The major objectives were to identify

- reasons why professional nurses requested their names to be removed from the SANC's register; and

- factors which could prohibit or facilitate their professional re-entry.

In order to contextualise these findings information was also requested about personal data such as age, marital status, professional and academic qualifications.

\section{SIGNIFICANCE OF THE RESEARCH}

The nursing profession and the entire health care system could benefit if factors should become apparent, which caused professional nurses to abandon their profession to the extent of requesting the removal of their names from the SANC's register, and/or which might prevent their professional re-entry.

Knowledge about factors that encourage nurses to leave their profession, and those which might prohibit their return, could help health care planners to address the anticipated depletion of professional nurses in the $\mathrm{RSA}$; and to contribute to the avoidance of a potential crises arising from such severe shortages of professional nurses in the RSA between 2005 and 2020.

\section{JUSTIFICATION FOR THE RESEARCH BASED ON A LITERATURE REVIEW}

\section{Baby-boomers}

Almost two decades ago, Cilliers (1984:74) warned that the then median age of 38 years (estimated to exceed 47 years of age in 2003) of the professional nurses in the RSA, should alert health care planners to an anticipated severe shortage of professional nurses as from 2005 when the median age of professional nurses could be expected to exceed 49 years of age. Cilliers (1984:74) forecasted that the majority of these professional nurses would retire between 2010 and 2015 , if they chose to retire between the ages of 60 and 65 . However, should the majority choose to retire between the ages of 55 and 60 , this crisis could be expected to occur as early as between 2005 and 2010 .

This situation is not unique to the RSA. In the USA researchers warn about the effect of retirement by the baby boomers - the group that makes up the biggest cohort of professional nurses in the USA. If baby boomers are defined as persons born between 1947 and 1962 , then $49 \%$ of professional nurses in the USA (in 1996) fell within this age group. Reportedly only $9 \%$ of professional nurses in the USA were younger than 30 years in 1996, implying that $91 \%$ of nurses in the USA were older than 30 years of age. Consequently the baby boomers' employment decisions could nullify any increased enrollment of student nurses in the USA. "If a large number of these boomers withdraw in a short (5-year) time span, there is the possibility that pressure on wages, and in turn, on the costs of health services, will be profound..." (Minnick, 2000:216). "In 2005, these "large cohort" boomers will begin to reach the age (55 years) at which RNs have historically begun to reduce their labor participation. By 2010, almost all of these RNs will be in what have traditionally been prime retirement years .... The major reasons for unemployment are retirement, disability, and child or elder care. More than half of non working nurses are older than 60 years of age. Only $1.4 \%$ RNs reported 
looking for employment" (Minnick, 2000:211). Previous mechanisms used for addressing nurse shortages, involved attracting non-practising nurses to re-enter the profession. Minnick's (2000:211) report indicates that, at least in the USA, there is no longer a pool of nonpractising nurses who could be enticed into re-entering the nursing profession. Unlike the shortages of professional nurses of the 1980s, it will not be feasible to address these shortages in the $21^{\text {st }}$ century by increasing the supply due to the age (exceeding 50 years) of the majority of professional nurses globally (Buerhaus, 1998:107).

\section{Training more student nurses}

Theoretically, the shortage of professional nurses could be offset by training increased numbers of student nurses. In practice, this apparent solution does not seem to succeed in increasing the number of practicing professional nurses in most countries. In the RSA, large numbers of newly qualified professional nurses seem to leave the RSA to work in the USA, the UK, Australia, Canada, New Zealand and in the Middle East countries such as Bahrain and Saudi Arabia (DENOSA, 2001:1). During 1999, an estimated 3300 professional nurses emigrated from the RSA and 200 professional nurses approached the South African Nursing Council for overseas registration on a monthly basis (DENOSA, 2001:10). In the RSA the total number of student nurses following the four-year comprehensive (R425) programme declined from 11903 in 1997 to 9639 in 2001 (DENOSA, 2001:6). Such a decline in the number of student nurses in the RSA, emphasises the importance of monitoring the migration of professional nurses from the RSA in order to address potential crises in the health care sector due to severe shortages of professional nurses.

In the UK newly qualified professional nurses seem to be inadequate. Reportedly $20 \%$ of the UK's student nurses do not register for practice when they've finished their training (Milburn, 2001:40) because they do not wish to practise as professional nurses. The situation in the UK is particularly serious because a survey indicated that half of England's nurses aged 30 or younger, intended abandoning the profession, leading to an expected shortage of 57000 professional nurses by 2004 (Ka Mzolo, 2001:38).
Similarly, estimates done in the USA indicated that nearly $60 \%$ of the practising professional nurses were older than 40 years of age, and that the percentage younger than 30 has decreased by almost $30 \%$ since 1980 (Buerhaus, Staiger \& Auerbach, 2000:111), apparently supporting Cilliers' (1984:47) warning about the high median age of South African nurses. (If large numbers of young South African nurses continue to emigrate, then this predicted median age could become progressively higher, aggravating the South African shortage of nurses when large numbers of its nurses reach retirement age).

In the USA researchers estimated that nursing schools could, within the period of one complete graduation cycle of four years, produce no more than a $15 \%$ to $20 \%$ increase in the numbers of their graduates. The major factors which impede a more rapid increase relate to lack of qualified nurse educators, facilities, and clinical sites. This global shortage of nurses is further aggravated by the apparent inability not only to recruit but also to train larger numbers of student nurses. This situation is likely to deteriorate even further because the average age of nurse educators worldwide is reportedly older than 50 . In the USA, $50 \%$ of the faculty in schools of nursing will retire by 2010 (Purnell et al. 2001:179), raising serious issues about the timely preparation of younger nurses to become nurse educators before 2010. In Texas (USA), “... thousands of individuals who apply to college nursing programs aren't accepted due to a lack of nursing faculty" (Christmas, 2002:20). Even if these increases could be realised, the possible impact on the total nursing work force in the USA would remain negligible, because newly qualified nurses represent less than $4 \%$ of the total number of professional nurses in the USA (Minnick, 2000:216). Apparently the USA does not succeed in training larger numbers of student nurses because student enrollments declined by $42 \%$ for diploma programmes, $19 \%$ for baccalaureate programmes and $11 \%$ for associate degree programmes between 1993 and 1996 in the USA (Letvak, 2002:387).

The global nursing education situation is hampered by the fact that graduates from doctoral nursing programmes are often in their fifties (Tanner \& Bellack, 2001:100), limiting the professional, academic and educational contributions that could be expected from 
these graduates.

\section{The effects of a severe shortage of nurses on the nursing profession}

If nursing, as a profession, cannot supply enough personnel, other occupational groups or even new types of workers may fill the gaps, such as auxiliary nurses, barefoot doctors or medical assistants. Health care planners need to act on labour participation/ withdrawal issues of nurses, because their withdrawal from practice could impact on health care standards and costs (Minnick, 2000:213). Brewer and Kovner (2001:20) also assert that this could be particularly important in the RSA where most Primary Health Care (PHC) services, constituting the backbone of the country's health care services, are provided by nurses. Access to health care cannot be achieved, nor maintained, without adequate numbers of professional nurses to organise and provide these services.

Furthermore, professional nurses in the RSA, especially but not exclusively in the rural areas, form a cultural bridge between foreign doctors from countries such as Cuba and Poland and the local health care clients (Ehlers, 2000:31). Without nurses who know both English and the local languages as well as the local cultures, the services of these non-English speaking doctors, who are unfamiliar with local customs and traditions, might have limited impact on the well-being of the people of the RSA.

The aging of the baby boomers and their ability to change the supply/demand balance with as little as a $5 \%$ to $10 \%$ change in their labour withdrawal rates, could have far reaching consequences for the nursing profession in the USA, and possibly also in the RSA. "If most of the withdrawal comes from in-demand specialty areas, nursing education, or nursing leadership, the very future of health care and the nursing profession could be altered in ways antithetical to the public good" (Minnick, 2000:217). The potential impact of large numbers of dissatisfied and emotionally exhausted nurses, working under undue stress due to shortages of professional nurses, on the quality of patient care and patient outcomes cannot be estimated (Aiken, Clarke, Sloane, Sochalski, Busse, Clarke, Giovannetti, Hunt, Rafferty \& Shamian, 2001:45). Studies done in the USA, estimated that health care errors (mainly medication errors) could kill between 44 000 and 98000 people per year, more than the number of persons who die from AIDS, traffic accidents, or breast cancer per year in the USA (Blouin \& Brent, 2000:293). Workload played a role in determining professional nurses' levels of reported job satisfaction/ dissatisfaction, as did “... positive relationships between work satisfaction, group cohesion, strong leadership, and retention rates and a negative relationship between stress, works schedule and retention" (Schader et al. 2001:210). However, the consequences of workload, such as unfinished nursing tasks at the end of a shift and the frequency of adverse events among patients, played a prominent role in determining nurses' levels of job satisfaction (Sochalski, 2001).

As the number of professional nurses continues to decrease in an institution, the workload of the remaining professional nurses continues to increase, leading to greater levels of job dissatisfaction, reduced levels of productivity and increased risks of suffering from "burnout". Maslach (in Booyens, 1998:147) defined burnout "....as an evolutionary process of growing emotional exhaustion, occurring in a nurse as a consequence of being exposed to chronic work-related stress factors". Nurses suffering from burnout become increasingly passive and negative, impacting negatively on their patients, institutions, employers and on themselves. Leiter, Harvie and Frizzelli (1998:1611) investigated the correspondence of patient satisfaction and nurse burnout and reported: "Patients on units where nurses found their work meaningful were more satisfied with all aspects of their hospital stay. Patients who stayed on units where nursing staff felt more exhausted or more frequently expressed the intention to quit were less satisfied with the various components of their care". Thus shortages of nurses impact negatively not only on nurses' workloads, exhaustion levels and intentions to stay in the nursing profession but also on levels of patient satisfaction with nursing care received.

The demands for home nursing services are expanding worldwide - in most countries attributable to their aging populations, and to the rapid discharge of patients from hospitals even after major surgery. In the RSA, and in a number of African countries, the HIV/AIDS pandemic require ever more home care facilities. Even if professional nurses do not provide all the home care services as such, they need to organise, co-ordinate 
and supervise these services.

\section{The retention of professional nurses in the active professional ranks}

Bozell (2001b) reports that "Recruiting and hiring qualified nurses can challenge your most creative efforts. It's a vicious cycle... bring nurses in the front door while others leave through the back door. And if you can't hang on to new and seasoned employees, your efforts are in vain". Bozell (2001a) further emphasises that personnel experts estimate that for each departing employee, an institution loses 1.5 times his or her salary, mostly due to recruiting costs, training time, and lost productivity of colleagues who need to fulfil another person's tasks in addition to their own full workloads.

Nurses' job stages of entry, mastery and disengagement are related to time on the job, skills development, and attitudes. Organisational commitment of professional nurses is related to mastery and to the prevention of disengagement. In times of change and financial pressures, nurses need support and job security to retain their ideals of service (McNeese-Smith, 2000:145-147). Managers who support professional nurses during times of change and financial insecurities, might indeed be exercising their best options for retaining professional nurses. "The importance of employees' expectations about future satisfaction is a major determinant of job movement" (Taylor \& Covaleski, 1985:237). Health care management's goal of assuring patient/client satisfaction may best be reached by providing a supportive environment that promotes meaningfulness of work and reduces or prevents burnout among nurses (Leiter et al. 1998:1616).

\section{CONCLUSION BASED ON THE LITERATURE REVIEW}

The literature reviewed indicates that approximately $50 \%$ of the nurses working in many countries of the world could be expected to retire between 2005 and 2020. This predicted shortage of nurses within the next decade, will be more critical than any previous shortage because there will be no large pool of non-practising nurses who can be recruited, because the majority of the professional nurses will have reached retirement age. The emigration of professional nurses to better paying countries will therefore continue to escalate, leaving the countries which pay poorer salaries, with extreme shortages of professional nurses. The RSA falls into the latter category.

The possibility of training increased numbers of student nurses seems to offer little scope for improving the provision of registered professional nurses within the foreseeable future - based on research done in the RSA, the USA and the UK - which indicates that the numbers of registered student nurses continue to decline in these three countries. The consequences of severe shortages of nurses impact negatively on the quality of care with expected increased occurrences of medico-legal risks.

Efforts to retain registered nurses within the active professional ranks may help to address the potential problem of anticipated nurse shortages - even if only for a 5-10 year period. Such efforts would need to consider reasons why nurses leave the nursing profession as well as factors which might prohibit or facilitate their professional re-entry. This study attempted to identify reasons why nurses left the nursing profession, by requesting their names to be removed from the SANC register, as well as conditions under which they would consider re-entering the nursing profession. The research process and results will be discussed in the next article.

\section{LIST OF REFERENCES}

AIKEN, LH; CLARKE, SP; SLOANE, DM; SOCHALSKI, JA; BUSSE, R; CLARKE, H; GIOVANNETTI, P; HUNT, J; RAFFERTY, AM \& SHAMIAN, J 2001: Nurses' reports on hospital care in five countries. Health Affairs, 20(3):43-53.

BLOUIN, AS \& BRENT, NJ 2000: Happy Y2K new and old challenges for the nurse administrator. Journal of Nursing Administration, 30(6):292-294 .

BOOYENS, SW (ed.) 1998: Dimensions of nursing management; $2^{\text {nd }}$ edition. Kenwyn: Juta.

BOZELL, J 2001(a): Recruitment and retention report. Create curb appeal. SpringNet - Nursing Communities - Nurse Managers. (http:/ /www/springnet.com/content/nm/0008/nm8rr.htm; accessed on 25 September 2001).

BOZELL, J 2001(b): Recruitment and retention report. Breaking the vicious cycle. SpringNet - Nursing Communities - Nurse Managers. (http://www/springnet.com/content/nm/0008/nm8rr.htm; 
accessed on 25 September 2001).

BREWER, C \& KOVNER, CT 2001: Is there another nursing shortage? What the data tell us. Nursing Outlook, 49(1):20-26. BUERHAUS, PI 1998: Is another RN shortage looming? Nursing Outlook, 46(3):103-108.

BUERHAUS, PI; STAIGER, DO \& AUERBACH, I 2000: Why are shortages of hospital RNs concentrated in specialty care units? Nursing Economics, 18(3):111-116.

CHRISTMAS, K 2002: Recruitment and retention report: invest internationally. Nursing Management, November 2002:20-21. CILLIERS, G1984: Occupational study of nurses. Part 3. The work situation of nurses two years after qualifying. Pretoria: Human Sciences Research Council (HSRC).

COLOSSI, ML 2002: In my opinion ... rules of engagement for the nursing shortage. JONA's Healthcare Law, Ethics and Regulation, 4(3):50-54.

DENOSA 2001: Migration of nurses: realities, threats, challenges, the way forward. Report of a workshop organised by the Industrial Relations Committee, National Board, DENOSA. 1 September 2001. Pretoria: DENOSA Head Office.

EHLERS, VJ 2000: Nurses as advocates between western and traditional health practices in the RSA. Health SA Gesondheid, 5(2):29-36).

KA MZOLO, B 2001: Global migration of nurses: a vexing problem. Nursing Update, 25(9):38.

LEITER, MP; HARVIE, P \& FRIZZELI, C 1998: The correspondence of patient satisfaction and nurse burnout. Social Science \& Medicine, 47(10):1611-1617.

LETVAK, S 2002: Retaining the older nurse. Journal of Nursing Administration, 32(7/8):387-392.

MCNEESE-SMITH, DK 2000: Job stages of entry, mastery, and disengagement among nurses. Journal of Nursing Administration, 30(3):140-147.

MILBURN, A 2001: NHS Plan - nurses really can make a difference. RCN (Royal College of Nursing) Magazine, Winter 2000/ 2001:38-41.

MINNICK, AF 2000: Retirement, the nursing workforce, and the year 2005. Nursing Outlook, 48(5):211-217.

NEWS FROM NINR (National Institute of Nursing Research). Nursing Shortage. 2003: (Online: http://www.nih.gov/ninr/news-info/ pubs/outlookmay01.html).

PURNELL, MJ; HORNER, D; GONZALES, J \& WESTMAN, N 2001: The nursing shortage: revisioning the future. Journal of Nursing Administration, 31(4):179-186.

SCHADER, K; BROOME, ME; BROOME, CD; WEST, ME \& NASH, $M$ 2001: Factors influencing satisfaction and anticipated turnover for nurses in an academic medical center. Journal of Nursing Administration, 31(4):210-216.

SOCHALSKI, J 2001: Quality of care, nurse staffing, and patient outcomes. Policy, Politics and Nursing Practice, 2(1). (EBSCO

Online- Article: http://www.us.ebsco.com/online/ direct.asp?ArticleID=2U90WR1QVVB4FNVTC0DP\&Target=Abstract). TANNER, CA \& BELLACK, JP 2001: Editorial: resolving the nursing shortage: replacement plus one. Journal of Nursing Education, 40(3):99-100.

TAYLOR, MA \& COVALESKI, MA 1985: Predicting nurses' turnover and internal transfer behavior. Nursing Research, 34(4):237-241. 